\title{
Rafał Leśniczak*
}

\section{Rola aktów illokucyjnych}

w kształtowaniu wizerunku prasowego

Konferencji Episkopatu Polski

Studium ogólnopolskich dzienników

„Gazeta Wyborcza” i „Rzeczpospolita”

\section{Wprowadzenie - zagadnienia metodologiczne}

W podjętych badaniach autor odnosi się do pragmatycznej analizy działań językowych Johna Langshawa Austina. Teoria aktów mowy brytyjskiego filozofa i językoznawcy wyraża pragmatyczny sposób podejścia do języka. W pierwszym okresie prowadzonych badań brytyjski filozof analityczny wskazał istnienie dwóch rodzajów zdań oznajmujących: zdania konstatujące (deskryptywne) i wypowiedzi performatywne ${ }^{1}$. Pierwsze $\mathrm{z}$ wymienionych wypowiedzi opisują rzeczywistość zastaną, z kolei drugi rodzaj wypowiedzi jest wykonaniem określonej czynności². Zdania konstatujące podlegają kryteriom prawdziwości/fałszu, natomiast performatywy są raczej wykonaniem określonej czynności, nie opisują one niczego, stąd nie mogą być postrzegane w kategoriach prawdy i fałszu ${ }^{3}$. W dalszych latach badań Austin stwierdził brak jasnych kryteriów takiego podziału (na wypowiedzi konstatujące i performatywne) i zaproponował podział składników aktów mowy

* Dr, Wydział Teologiczny, Uniwersytet Kardynała Stefana Wyszyńskiego w Warszawie, e-mail: r.lesniczak@uksw.edu.pl.

1 Por. J.L. Austin, Wypowiedzi performatywne, [w:] tenże, Mówienie i poznawanie. Rozprawy i wykłady filozoficzne, przeł. B. Chwedeńczuk, Warszawa 1993, s. 314.

2 J. Reichert, Sprechakttheorie nach John Langshaw Austin, München 2009, s. 5-16.

3 G. Osika, Procesy i akty komunikacyjne, Kraków 2011, s. 80. 
na lokucyjne, illokucyjne i perlokucyjne ${ }^{4}$. Brytyjski filozof zauważył bowiem, że konstatacjom może w niektórych sytuacjach przysługiwać wartość performatywna, stąd jego decyzja o przeformułowaniu teorii ${ }^{5}$. Punktem wyjścia było pytanie o możliwość stosowania języka w sytuacji, gdy mówienie staje się wykonaniem określonego działania ${ }^{6}$. Austin na tak postawioną kwestię udzielił odpowiedzi pozytywnej. W konsekwencji wyróżnił grupę sensów „robienia czegoś” występujących wspólnie. Dla Austina „mówić coś” to w pewnym normalnym sensie „robić coś”7. Ten rodzaj czynności nazwał on czynnością lokucyjną. Akt lokucyjny stanowi zatem wygłoszenie jakiejś zrozumiałej, mającej sens wypowiedzi. Z kolei akt illokucyjny jest wykonaniem czynności kryjącej się w powiedzeniu czegoś. Austin wyróżnia także tzw. akty perlokucyjne, w których powiedzenie czegoś wywołuje często, choć jest to w dużym stopniu nieprzewidywalne, określone skutki w sferze uczuć, myśli lub działań odbiorców.

Celem prezentowanego artykułu jest próba określenia roli, jaką wypełniają zastosowane $\mathrm{w}$ tekstach dziennikarskich czasowniki illokucyjne verdictives, exercitives, commissives, behabitives, expositives $\mathrm{w}$ odniesieniu do wizerunku prasowego hierarchii Kościoła katolickiego w Polsce w aspekcie komunikowania politycznego Konferencji Episkopatu Polski (KEP). Analizą zostaje objęty okres od zakończenia drugiej tury wyborów prezydenckich w $2015 \mathrm{r}$. aż do momentu zaprzysiężenia nowo wybranego Prezydenta Rzeczypospolitej Polskiej. Kontekst badań stanowi zatem wybór Andrzeja Dudy na urząd najwyższego przedstawiciela polskich władz. Należy wyraźnie zaznaczyć, że autor niniejszej pracy koncentruje swoją uwagę jedynie na sposobie prezentacji zaangażowania politycznego biskupów polskich na rzecz nowo wybranego prezydenta w ogólnopolskich dziennikach „Gazeta Wyborcza” („GW”) i „Rzeczpospolita” („Rz”). Podjęte studium przypadku nie obejmuje zatem analizy prasowej pod kątem wszystkich cech składowych wizerunku (np. sposobu postrzegania KEP z punktu widzenia wieku i wykształcenia jego członków, pochodzenia czy stanu majątkowego oraz wieku), ale jedynie koncentruje się na zaangażowaniu na rzecz polityków polskiej prawicy. Ściśle rzecz biorąc, niniejsze studium przypadku obejmuje relację zagadnień z zakresu językoznawstwa i nauk o mediach.

Autor skonfrontuje oficjalne stanowisko KEP odnoszące się do wyniku wyborczego z 25 maja 2015 r. z echami prasowymi dzienników „Rzeczpospolita” i „Gazeta Wyborcza”, wskazując ewentualne różnice, i dokona próby uchwycenia roli tzw. czasowników illokucyjnych w formowaniu wizerunku polskich hierarchów.

4 D. Zdunkiewicz, Akty mowy, [w:] Współczesny język polski, red. J. Bartmiński, Wrocław 1993, S. $260-261$.

5 Tamże, s. 260.

6 G. Osika, dz. cyt., s. 84.

7 Por. J.L. Austin, dz. cyt., s. 640. 
Zastosowane w tekstach wypowiedzi illokucyjne niekoniecznie muszą eksponować poglądy autorów tekstów w odniesieniu do obrazu KEP. Mogą pełnić w tekście inną rolę i nie mieć związku z podjętym tematem niniejszej publikacji naukowej. Zostanie to wyeksponowane w prezentacji wyników analizy.

Zakres czasowy analizy obejmuje okres od 25 maja 2015 r. do 15 sierpnia 2015 r., czyli od zakończenia drugiej tury wyborów prezydenckich do okresu bezpośrednio następującego po zaprzysiężeniu Andrzeja Dudy, które odbyło się 6 sierpnia 2015 r. Czas analizy to także dni od 7 sierpnia do 15 sierpnia 2015 r., ponieważ okres ten gwarantuje autorowi wgląd w echa prasowe oficjalnego objęcia urzędu Prezydenta RP.

Materiał badawczy stanowią artykuły drukowanych wersji dzienników „Gazeta Wyborcza” i „Rzeczpospolita”, w których pojawia się jedno z następujących słów: „biskupi”, „Konferencja Episkopatu Polski”, „hierarchowie”, „,duchowni” oraz jednocześnie słowo „prezydent”, „elekt”, „Duda”, „wybory”. W podjętej analizie autor pomija te teksty prasowe, $\mathrm{w}$ których słowa „prezydent” lub „wybory” przynajmniej jeden raz nie odnoszą się do Dudy, jak również te teksty, w których termin „duchowni” nie ma żadnego związku z duchownymi katolickimi czy KEP.

Teoretycznie, użyte w tekstach słowo „prezydent” może bowiem odnosić się np. do prezydenta innego państwa, termin „wybory” może dotyczyć wyborów parlamentarnych lub wyborów władz uczelni, a termin „hierarchowie” może odnosić się do duchownych innych Kościołów chrześcijańskich lub duchownych innych państw niż Polska.

Wyżej wymienione kryteria spełnia ogółem 10 artykułów opublikowanych w „Rzeczpospolitej” i 25 artykułów zamieszczonych na łamach „Gazety Wyborczej”. Całościowy wykaz tekstów dziennikarskich spełniających założenia metodologiczne znajduje się w bibliografii.

W niniejszym artykule uwaga zostaje skoncentrowana na aktach illokucyjnych, które charakteryzuje użycie tzw. czasownika illokucyjnego. Austin proponuje następującą klasyfikację tychże czasowników:

1. verdictives - są to czasowniki osądzające służące do wydawania werdyktu lub orzekania o czymś, np.: uznaję, postanawiam, uważam, uniewinniam, szacuję, rozumiem;

2. exercitives - są to czasowniki używane do wywierania wpływu oraz wydawania praw, np.: mianuję, degraduję, kieruję, nominuję, zwalniam;

3. commissives - są to takie czasowniki, których użycie w wypowiedzi ma na celu zobowiązanie się mówiącego do wykonania określonych działań, np.: obiecuję, daję słowo, zamierzam, planuję;

4. behabitives - są to czasowniki odnoszące się do reakcji na zachowanie innych osób, przyjmowanie i wyrażanie postaw wobec innych oraz wszelkie ogólnie pojmowane zachowania społeczne, np.: przepraszam, dziękuję, gratuluję, błogosławię, wznoszę toast; 
5. expositives - są to czasowniki służące do przedstawienia poglądów, przeprowadzenia argumentacji oraz wyjaśniania użycia wyrażeń, np.: opisuję, oceniam, twierdzę, wątpię, informuję, podkreślam ${ }^{8}$.

Pod pojęciem wizerunek prasowy autor w przedstawianym artykule rozumie zbiór przekonań, myśli, opinii, wrażeń osoby lub grupy osób o jakiejś innej osobie, rzeczy lub instytucji, które są prezentowane na łamach prasy. Sposób postrzegania i prezentacji obiektu badawczego obejmuje szereg cech, takich jak przekonania, postawy, poglądy polityczne, społeczne. Wizerunek prasowy to zatem swoista mozaika wielu szczegółów, które dokonujący badania wyraża przy pomocy określonego stylu językowego i zastosowanych środków językowych?

\section{Przekaz instytucjonalny Konferencji Episkopatu Polski po zakończonych wyborach prezydenckich w 2015 r.}

Oficjalny, instytucjonalny przekaz polskiej hierarchii Kościoła katolickiego, wyrażający jej zaangażowanie polityczne wobec nowo wybranego Prezydenta RP, wyraził się zasadniczo w liście gratulacyjnym Prezydium Konferencji Episkopatu Polski z dnia 25 maja $2015 \mathrm{r}^{10}$ oraz podczas uroczystości zaprzysiężenia w dniu 6 sierpnia $2015 \mathrm{r}$., w czasie której słowo wprowadzenia do Mszy św. o błogosławieństwo dla nowego prezydenta wygłosił abp Stanisław Gądecki ${ }^{11}$, a homilię prymas Polski abp Wojciech Polak ${ }^{\mathbf{1 2}}$.

Dokonując próby odnalezienia w wymienionych dokumentach treści prezentujących jakikolwiek stopień zaangażowania politycznego KEP, należałoby zauważyć, że list z 25 maja wyraża jedynie życzenia sprostania licznym wyzwaniom stojącym przed nowo wybranym prezydentem, które są przypomnieniem przez prezydium KEP o obowiązkach związanych z piastowaniem najwyższego urzędu państwowego ${ }^{13}$. Z kolei słowo abp. Gądeckiego podkreśla brak jakichkolwiek aspi-

8 J.L. Austin, How to Do Things with Words, Oxford 1975, S. 151-164; A.P. Martinich, Communication and Reference, Berlin 1984, s. 56; G. Osika, dz. cyt., s. 87-88.

9 Por. K. Wojcik, Public Relations od A do Z, t. 2, Warszawa 1997, s. 44.

10 List gratulacyjny Prezydium KEP do Prezydenta Andrzeja Dudy, 25.05.2015, http://episkopat.pl/ list-gratulacyjny-prezydium-kep-do-prezydenta-andrzeja-dudy/ [dostęp: 12.08.2016].

11 Wstęp abp. Stanisława Gądeckiego do Mszy świętej inaugurującej urzędowanie nowego Prezydenta Rzeczpospolitej Polskiej, 6.08.2015, http://episkopat.pl/wstep-do-mszy-swietej-inaugurujacejurzedowanie-nowego-prezydenta-rzeczpospolitej-polskiej/ [dostęp: 12.08.2016].

12 Homilia Prymasa Polski abp. Wojciecha Polaka wygłoszona podczas Mszy Świętej w dniu zaprzysiężenia Prezydenta RP Andrzeja Dudy, 6.08.2015, http://episkopat.pl/homilia-prymasapolski-abp-wojciecha-polaka-wygloszona-podczas-mszy-swietej-w-dniu-zaprzysiezeniaprezydenta-rp-andrzeja-dudy/ [dostęp: 12.08.2016].

13 "Szanowny Panie Prezydencie! Prosimy o przyjęcie serdecznych gratulacji z okazji wyboru na Prezydenta Rzeczypospolitej Polskiej. Pierwsze informacje medialne mówią o przeważeniu 
racji politycznych hierarchii Kościoła w sensie pragnienia sprawowania władzy politycznej ${ }^{14}$. Abp Polak w wygłoszonej homilii zwrócił uwagę, że Kościół modli się za wierność Prezydenta RP zobowiązaniom wynikającym z troski o dobro Ojczyzny ${ }^{15}$.

W przekazie instytucjonalnym brak zatem poparcia politycznego polskich biskupów dla Dudy, czy, patrząc również szerzej, dla jakiejkolwiek partii politycznej, w tym partii Prawo i Sprawiedliwość, do której należał prezydent elekt.

\section{Hipotezy badawcze}

Zważywszy, że przedstawiany tekst stanowi próbę określenia stopnia zastosowania przez autorów analizowanych tekstów dziennikarskich czasowników illokucyjnych i próbę wskazania sposobu ich wykorzystania w sposobie prezentacji KEP $\mathrm{w}$ wymiarze jego zaangażowania politycznego na rzecz nowo wybranego prezy-

szali zwycięstwa w dużej mierze przez ludzi młodych. Większość rodaków, w tym także młodzi, łączy z Pańską prezydenturą wiele nadziei. Spełnienie płynących z tej funkcji zadań - z Bożą pomocą - będzie możliwe, jeśli da się osiągnąć porozumienie w obliczu najtrudniejszych wyzwań. Ufamy, że wysiłek wszystkich Rodaków w czasie Pańskiej prezydentury będzie umacniany świadomością wspólnej odpowiedzialności za Ojczyznę, Europę i świat. Życzymy Panu Prezydentowi skutecznego jednoczenia Polaków wokół spraw najważniejszych dla Polski oraz darów Ducha Świętego w sprawowaniu najwyższego urzędu w Państwie. Niech światło Ducha Świętego towarzyszy Panu Prezydentowi w podejmowaniu ważnych decyzji i w codziennej służbie dla Rzeczypospolitej” (List gratulacyjny Prezydium KEP...).

14 „Bądź też w pełni przekonany o tym, że kiedy Kościół - w czasie Twojego urzędowania - zabierze głos w sprawach związanych z życiem społecznym i politycznym, to nie w tym celu, by sprawować władzę polityczną albo odbierać komukolwiek prawa do wolności opinii w konkretnych sprawach. Kościół pragnie jedynie kształtować i oświecać sumienia wiernych - a zwłaszcza tych, którzy poświęcają się działalności politycznej - by ich wysiłki przyczyniały się zawsze do integralnego postępu człowieka i dobra wspólnego. Przez swoje nauczanie społeczne Kościół nie pragnie uczestniczyć w rządzeniu Polską. Niewątpliwie natomiast nakłada na wiernych moralny obowiązek wierności przekonaniom; obowiązek wpisany w ich sumienie, które jest jedno i niepodzielne" (Wstęp abp. Stanisława Gądeckiego do Mszy świętej...).

15 „Przed chwilą w naszym Parlamencie nowy Prezydent Rzeczypospolitej Polskiej, za którego w tej Eucharystii szczególnie się modlimy, składając wobec Zgromadzenia Narodowego uroczystą przysięgę, zobowiązał się do dochowania wierności postanowieniom Konstytucji, do niezłomnej obrony godności Narodu, do troski o niepodległość i bezpieczeństwo Państwa, a także do tego, że dobro Ojczyzny i pomyślność wszystkich obywateli będą dla niego zawsze najwyższym nakazem. Wypełnienie tych zobowiązań, staje się dla Pana, szanowny Panie Prezydencie, praktycznym wyrazem troski o dobro wspólne, a przez to - zgodnie ze słowami papieża Franciszka - doskonałą formą miłości" (Homilia Prymasa Polski abp. Wojciecha Polaka...). 
denta Dudy, ten sposób zaprezentowania stanowiska polskich biskupów zostanie skonfrontowany $z$ instytucjonalnym przekazem.

Cel badawczy wyraża się w sformułowaniu pytań badawczych, a w konsekwencji prowadzi do postawienia hipotez badawczych, które zostaną zweryfikowane po dokonaniu interpretacji danych uzyskanych z analizy ilościowej i jakościowej tekstów dziennikarskich.

Autor stawia zatem następujące pytania badawcze:

1. Jaki jest stopień intensywności zastosowania aktów illokucyjnych?

2. Która $\mathrm{z}$ kategorii verdictives, exercitives, commissives, behabitives, expositives dominuje w poddanych analizie tekstach?

3. Czy obecność tzw. czasowników illokucyjnych determinuje sposób przedstawiania Konferencji Episkopatu Polski jako aktora politycznego po zakończonych wyborach prezydenckich w 2015 r.?

4. Czy zastosowane czasowniki illokucyjne mają związek $\mathrm{z}$ ewentualnie formułowanymi przez autorów ogólnopolskich dzienników ocenami zaangażowania politycznego KEP?

5. Czy istnieje zbieżność w prezentowaniu linii politycznej KEP między tekstami prasowymi, w których są zawarte czasowniki illokucyjne a tekstami, gdzie nie odnotowuje się ich obecności?

Na podstawie pytań badawczych autor formułuje następujące hipotezy badawcze:

1. W poddanych analizie tekstach w większości materiału badawczego można odnaleźć akty illokucyjne. Teksty analizowanych dzienników nie są jedynie formą agencji prasowej z notkami, informacjami pisanymi bezosobowo, $\mathrm{w}$ formie 3. osoby, ale redaktorzy pracujący w redakcjach i kojarzeni z konkretnymi poglądami wyrażają w tych artykułach swoje stanowisko, stąd zastosowanie tzw. czasowników illokucyjnych.

2. Opiniotwórczość domaga się wyrażania własnych poglądów, przeprowadzenia argumentacji, wyjaśnienia zastosowanych wyrażeń, stąd kategoria expositives dominuje w tekstach spełniających kryteria metodologiczne.

3. Obecność tzw. czasowników illokucyjnych nie determinuje sposobu przedstawiania Konferencji Episkopatu Polski jako aktora politycznego po zakończonych wyborach prezydenckich w 2015 r. Zważywszy, że „Gazeta Wyborcza” i „Rzeczpospolita" należą do najbardziej opiniotwórczych polskich mediów, można spodziewać się, że - oprócz serwisu informacyjnego - teksty będą odzwierciedlać ogólną linię programową redakcji, w tym również linię polityczną ${ }^{16}$. Dlatego też autor analizy stawia hipotezę o tworzeniu przez „Gazetę Wyborczą” wizerun-

16 Por. Najbardziej opiniotwórcze polskie media w 2015 roku. Analiza częstotliwości cytowania poszczególnych mediów przez inne media na podstawie przekazów prasowych, telewizyjnych i radiowych z okresu od 1 stycznia do 31 grudnia 2015 roku, http://www.imm.com.pl/sites/default/files/raporty/ najbardziej_opiniotworcze_media_w_2015.pdf [dostęp: 12.08.2016]; Ustawa Prawo prasowe z dnia 
ku KEP jako podmiotu zaangażowanego politycznie we wspieranie prezydenta elekta Dudy. Z kolei sposób zaprezentowania linii politycznej KEP na łamach „Rzeczpospolitej” jest zbliżony do komunikatu instytucjonalnego polskich biskupów ${ }^{17}$. W opinii autora, czasowniki illokucyjne stanowią jeden ze sposobów odzwierciedlenia linii programowej gazety, ale nie jedyny (mogą to być np. także zastosowane figury retoryczne i sposoby erystyczne).

4. Czasowniki illokucyjne wzmacniają wcześniej wybrane stanowisko tytułu prasowego dotyczące sposobu prezentacji KEP jako aktora zaangażowanego bądź niezaangażowanego politycznie.

5. Istnieje zbieżność w prezentowaniu linii politycznej KEP między tekstami prasowymi, w których są zawarte czasowniki illokucyjne a tekstami, gdzie nie odnotowuje się ich obecności.

26 stycznia 1984 r., art. 10.2, http://www.krrit.gov.pl/Data/Files/_public/Portals/o/regulacje-prawne/polska/prawo-prasowe.pdf [dostęp: 12.08.2016].

17 O opcji liberalnej „Gazety Wyborczej”, w której krytykuje się instytucję Kościoła katolickiego za konserwatyzm w kwestiach przemian dokonujących się we współczesnym świecie można przeczytać m.in. w następujących publikacjach: J. Sławek, Obraz Kościoła katolickiego na łamach polskiej prasy codziennej z perspektywy realizowanych stereotypów, [w:] Język religijny dawniej i dziś, t. 1, red. S. Mikołajczak, ks. T. Węcławski, Poznań 2004, s. 396-406; F. Kucharczak, Jak Kościół tamał cieszę wyborcza, http://gosc.pl/doc/2505426.Jak-Kosciol-lamal-cisze-wyborcza [dostęp: 12.08.2016]; A. Dmochowski, Kościół „Wyborczej”. Największa operacja resortowych dzieci, Lublin 2014. Szczególnie ta ostatnia pozycja zawiera bardzo bogate odniesienie do materiału faktograficznego, potwierdzające, że misją „GW” jest przedstawianie wykrzywionego obrazu hierarchii Kościoła katolickiego w Polsce, tzn. ukazującego brak spójności w podejmowanej misji i nauczaniu. W opinii Pawła Lisickiego „Rzeczpospolita” jest gazetą konserwatywno-liberalną, która nie wykazuje zaangażowania po stronie jednego tylko ugrupowania partyjnego, oferuje natomiast szeroką przestrzeń dyskusji różnych ugrupowań. Konserwatyzm ujawnia się w sferze obyczajowej i w sferze odniesienia do tradycji i historii. Z tego też powodu „Rzeczpospolita” legitymizuje rolę Kościoła w społeczeństwie jako publiczną, a nie tylko prywatną (P. Lisicki, Paweł Lisicki o miejscu "Rzeczpospolitej” na mapie polskiej prasy, pęknięciach na prawicy oraz o głębokim sensie wydarzeń po 10 kwietnia, rozm. przeprowadziła K. Wigura, „Kultura Liberalna” 2011, nr 3, 18.01., http://kulturaliberalna. pl/2011/01/18/pawel-lisicki-o-„,rzeczpospolitej”-polskiej-prawicy-i-scenie-publicznej-po-10-kwietnia/ [dostęp: 12.08.2016]. Dość dobrze różnice w budowaniu wizerunku Kościoła przez "Gazetę Wyborczą" i „Rzeczpospolitą" ukazuje Anna Wittenberg na przykładzie wskazania różnych interpretacji tych samych danych empirycznych: A. Wittenberg, "Gazeta Wyborcza" $i$ „Rzeczpospolita” manipuluja czy działaja zgodnie z liniq? Statystyki w służbie ideologii, http:// natemat.pl/21123,gazeta-wyborcza-i-rzeczpospolita-manipuluja-czy-dzialaja-zgodnie-z-linia-statystyki-w-sluzbie-ideologii [dostęp: 12.08.2016]. 


\section{Analiza ilościowa i jakościowa}

\section{Określenia wskazujące na moc illokucyjną}

Kryteria metodologiczne analizy spełniło 35 tekstów. Spośród nich w 14 tekstach „Gazety Wyborczej" odnotowuje się obecność określeń wskazujących na moc illokucyjną (co stanowi 56\% tekstów „GW” spełniających kryteria metodologiczne analizy), zaś w „Rzeczpospolitej” - pięć (50\% tekstów spełniających kryteria metodologiczne analizy). Łącznie zatem w 19 tekstach obydwu dzienników autorzy zastosowali przynajmniej jeden czasownik illokucyjny, co stanowi 54,28\% próby badawczej.

Tabela 1 prezentuje zestawienie liczby tekstów opublikowanych w „Gazecie Wyborczej” i w „Rzeczpospolitej”, w których odnotowano obecność przynajmniej jednego czasownika illokucyjnego.

Tabela 1. Obecność czasowników illokucyjnych w „Gazecie Wyborczej” i „Rzeczpospolitej”

\begin{tabular}{|l|c|c|c|}
\hline & „Gazeta Wyborcza” & „Rzeczpospolita” & Ogółem \\
\hline $\begin{array}{l}\text { Teksty, w których jest } \\
\text { obecny przynajmniej jeden } \\
\text { czasownik illokucyjny }\end{array}$ & 14 & 5 & 19 \\
\hline $\begin{array}{l}\text { Teksty, w których nie } \\
\text { stwierdzono czasowników } \\
\text { illokucyjnych }\end{array}$ & 11 & 5 & 16 \\
\hline
\end{tabular}

Źródło: opracowanie własne.

Z kolei Tabela 2 przedstawia łączną liczbę poszczególnych czasowników illokucyjnych znajdujących się w tekstach „Gazety Wyborczej” i „Rzeczpospolitej”, przyporządkowanych do kategorii verdictives, exercitives, commissives, behabiti-

Tabela 2. Verdictives, exercitives, commissives, behabitives, expositives w analizowanych tekstach "Gazety Wyborczej” i „Rzeczpospolitej”

\begin{tabular}{|l|c|c|c|}
\hline & "Gazeta Wyborcza” & „Rzeczpospolita” & Ogółem \\
\hline verdictives & 9 & 6 & 15 \\
\hline exercitives & 0 & 0 & 0 \\
\hline commissives & 2 & 2 & 4 \\
\hline behabitives & 3 & 1 & 4 \\
\hline expositives & 9 & 2 & 11 \\
\hline
\end{tabular}

Źródło: opracowanie własne. 
ves, expositives. Są tu zatem czasowniki wpływające na postrzeganie KEP oraz te, które nie odnoszą się do budowania jej wizerunku. Tabela 3 prezentuje natomiast zestawienie tylko tych czasowników illokucyjnych, które mają związek z wizerunkiem prasowym polskich biskupów.

Tabela 3. Verdictives, exercitives, commissives, behabitives, expositives w analizowanych tekstach „Gazety Wyborczej” i „Rzeczpospolitej”, które odnoszą się do budowania wizerunku prasowego KEP po zakończonej drugiej turze wyborów prezydenckich w 2015 r.

\begin{tabular}{|l|c|c|c|}
\hline & „Gazeta Wyborcza” & „Rzeczpospolita” & Ogółem \\
\hline verdictives & 8 & 6 & 14 \\
\hline exercitives & 0 & 0 & 0 \\
\hline commissives & 1 & 0 & 1 \\
\hline behabitives & 1 & 1 & 2 \\
\hline expositives & 6 & 2 & 8 \\
\hline
\end{tabular}

Źródło: opracowanie własne.

Kategoriami dominującymi wśród zastosowanych czasowników illokucyjnych, które odnoszą się do budowania wizerunku prasowego KEP po zakończonej drugiej turze wyborów prezydenckich w 2015 r., są verdictives i expositives. Najmniej reprezentatywne okazują się commissives oraz behabitives. Autor nie stwierdził obecności exercitives w próbie badawczej.

Kategorię verdictives reprezentuje 15 tekstów prasowych ${ }^{18}$. Spośród nich 14 następujących odnosi się do budowania wizerunku prasowego KEP po zakończonej drugiej turze wyborów prezydenckich w $2015 \mathrm{r}$.:

Podejrzewam, że sztab odchodzącego już prezydenta popełnił jeszcze jeden błąd. Oczekiwał, że Andrzej Duda zgodnie z tradycją polskiej prawicy będzie jasno odwoływał się do chrześcijańskich wartości, a także że otrzyma jasne poparcie Kościoła (czasownik illokucyjny verdictives; D. Zdort, Ciemny lud tego nie kupił, „Rzeczpospolita" 2015, 27.05, s. A6).

Nie chcę nikogo oskarżać o obłudę czy brak pokory, ale pewien umiar wydaje mi się konieczny. Zwłaszcza że ów udział prezydenta elekta w liturgiach jest wykorzystywany przez jego przeciwników politycznych (czasownik illokucyjny verdictives; T. Krzyżak, Politycy nie mogą żyć bez Kościoła, „Rzeczpospolita” 2015, 22.07, s. A9).

18 Autor pogrubioną czcionką wskazuje czasownik illokucyjny oraz podaje źródło. 
Wierzę, że jako ludzie wierzący, także dzięki tej modlitwie, zdołamy to zrealizować lepiej, uczciwej i rzetelniej (czasownik illokucyjny verdictives; tamże).

Gdyby ktoś z dziennikarzy zechciał taką dyskusję zanotować, to przypuszczam, że biskup Michalik nie miałby oporów (czasownik illokucyjny verdictives; T. Krzyżak, Księża kontra biskupi. Nowa linia podziału, „Rzeczpospolita” 2015, 11.08, s. A6).

Józef Życiński: [...] Myślę jednak, że bylibyście rozczarowani, bo różnice między nami nie są tak wielkie, jak można by sądzić (czasownik illokucyjny verdictives; źródło: tamże).

Henryk Gulbinowicz: Mam tylko nadzieję, że prezydent Duda będzie dobrze strzeżony, a nie tak jak śp. prezydent Lech Kaczyński. Boli mnie, że ta tragedia smoleńska wciąż nie została wyjaśniona (czasownik illokucyjny verdictives; źródło: H. Gulbinowicz, Ojczyzna jest wolna, rozm. przeprowadził J. Nizinkiewicz, „Rzeczpospolita” 2015, 12.08, s. A6).

Rozumiem, że w polskim Kościele irlandzkie referendum odczytano jako sygnał alarmowy. Skoro Irlandia była uważana za ostoję katolicyzmu, a „takie rzeczy” są możliwe, to co będzie z Polską? (czasownik illokucyjny verdictives; K. Wiśniewska, Co ma Boże Ciało do in vitro?, „Gazeta Wyborcza” 2015, 5.06, s. 4).

Jest oczywiste, że Kościół ma swoją misję i ma prawo wypowiadać się na te tematy. Ale mam wrażenie, że biskupi w ten sposób oddalają się od wiernych" (czasownik illokucyjny verdictives, D. Wielowieyska, Andrzej Duda i biskupi, „Gazeta Wyborcza" 2015, 9.06, s. 5).

Duda: - Do pewnego czasu rzeczywiście uważałem, że ten kompromis jest czymś, co ma charakter trwały, i że jakakolwiek zmiana przez wzmocnienie ochrony życia może grozić później działaniami odwetowymi w sensie pchania polskiego prawa w przeciwnym kierunku, czyli zmniejszania ochrony życia, to ten kompromis trzeba zachować (czasownik illokucyjny verdictives; J. Hołub, Radio Maryja: Dzięki Bogu wygrał Duda, „Gazeta Wyborcza” 2015, 16.06, s. 6).

„To wtedy zdecydowałem o opuszczeniu zakonu, w którym spędziłem 29 lat” - wspomina w swojej najnowszej książce pt. Polak katolik? prof. Stanisław Obirek, który dziś pracuje w Ośrodku Studiów Amerykańskich UW (czasownik illokucyjny verdictives; S. Obirek, Nie jest przesada mówienie o iranizacji Polski, rozm. przeprowadziła D. Wodecka, „Gazeta Wyborcza” 2015, 18-19.07, s. 30-31). 
Nie zgadzam się z zawartą w pani pytaniu supozycją, że krytyka polskiego katolicyzmu stała się powszechna (czasownik illokucyjny verdictives; tamże).

Ale znając historię związków tego wybitnego teologa z Janem Pawłem II i Benedyktem XVI, nie tylko przyznaję mu rację, ale także rozciągam jego tezę na polski katolicyzm, zwłaszcza w wersji prezentowanej przez hierarchów (czasownik illokucyjny verdictives; tamże).

Wróżę, że w ciągu najbliższych czterech lat obkurczy się nam i tak nikłe społeczeństwo obywatelskie: przestrzeń publiczna zostanie bez reszty wypełniona organizacjami i instytucjami kościelnymi, przykościelnymi i parafialnymi (czasownik illokucyjny verdictives; M. Środa, W czwartek, „Gazeta Wyborcza” 2015, 5.08, s. 2).

Spodziewam się więc, że abp Dzięga natychmiast publicznie potępi nowego prezydenta za przystąpienie do sakramentu komunii (czasownik illokucyjny verdictives; D. Wielowieyska, Abp Dzięga i jego rewolucja moralna, „Gazeta Wyborcza” 2015, 7.08, s. 8).

Jedynie jedno określenie wskazujące na moc illokucyjną, należące do kategorii verdictives, nie ma związku z budowaniem wizerunku polskich biskupów:

Wierzę, że Platforma może powiedzieć coś pozytywnego o swoich osiągnięciach $\mathrm{z}$ lat 2007-15 (czasownik illokucyjny verdictives; W. Orliński, Hejterami się nie wygrywa, „Gazeta Wyborcza” 2015, 12.06, s. 8).

Kategorię expositives reprezentuje ogółem 11 tekstów prasowych, spośród których osiem następujących odnosi się do wizerunku prasowego KEP po zakończonej drugiej turze wyborów prezydenckich w 2015 r.:

Henryk Gulbinowicz: Mam nadzieję, że prezydent Andrzej Duda będzie szanował historię państwa polskiego, które od 1050 lat jest ochrzczone (czasownik illokucyjny expositives; H. Gulbinowicz, dz. cyt.).

Powtarzam, prezydent nie powinien ukrywać swojego światopoglądu. Andrzej Duda został przez swoją rodzinę wychowany w katolicyzmie i może być z tego dumny (czasownik illokucyjny expositives; tamże).

Zastanawiam się, ilu polskich księży przemyciło podczas ciszy wyborczej podobne lub bardziej ostentacyjne wskazówki? (czasownik illokucyjny expositives; K. Wiśniewska, Czy Kościół pomógł Dudzie?, „Gazeta Wyborcza” 2015, 26.05, s. 8). 
Słuchałam uważnie kazań najważniejszych polskich hierarchów i zastanawiałam się, skąd się bierze ta osobliwa myśl teologiczna naszych biskupów: łączenie najważniejszych świąt, takich jak Boże Ciało (a także Boże Narodzenie, Wielkanoc), z tematyką in vitro, związków partnerskich, gender? (czasownik illokucyjny expositives; źródło: taż, Co ma Boże Ciało do in vitro?).

Ateizm - przypominam - jest intelektualną i duchową postawą, która może asymilować różne idee, przekonania, światopoglądy i której nie ogranicza wąski zbiór dogmatów i przesądów (czasownik illokucyjny expositives; M. Środa, Przyszłość należy do ateistów?, „Gazeta Wyborcza” 2015, 17.06, s. 2).

Państwo świeckie - przypominam, bo już mało kto pamięta - jest miejscem, gdzie funkcjonować mogą różne Kościoły, a ludzie o odmiennych światopoglądach żyją w poczuciu wolności i równości, gdzie władza - dokładnie jak głosili wygnani z kraju bracia polscy, a zasymilowani Anglicy - troszczy się o dobrobyt swoich obywateli, a Kościół o ich zbawienie (czasownik illokucyjny expositives; tamże).

Moim zdaniem, patrząc na przekrój gości, nie można stawiać zarzutów, że jest to Radio jednostronne - powiedział mi rzecznik archidiecezji wrocławskiej ks. Rafał Kowalski (czasownik illokucyjny expositives; K. Wiśniewska, Diecezjalne tuby PiS, „Gazeta Wyborcza” 2015, 24.06, s. 3).

Postuluję powołanie specjalnego trybunału dla tych spowiedników (czasownik illokucyjny expositives; D. Wielowieyska, Abp Dzięga i jego rewolucja moralna).

Z kolei trzy wypowiedzi illokucyjne $\mathrm{z}$ kategorii expositives nie mają związku z budowaniem wizerunku KEP:

Duda: [...] Wierzę, że wspólnym wysiłkiem doprowadzimy za rok w Warszawie do przełomowych decyzji, jeśli chodzi o bezpieczeństwo naszej części Europy (czasownik illokucyjny expositives; A. Kondzińska, To bzdura, że się nie da, „Gazeta Wyborcza" 2015, 7.08, s. 2).

Wydaje mi się to wszystko przypadkiem ogólnej prawidłowości, jaką jest trwające od dziesięciu lat ignorowanie internetu przez PO (przy jednoczesnym sprawnym długim marszu PiS) (czasownik illokucyjny expositives; W. Orliński, dz. cyt.).

Kaczyński (6 maja): - Jestem głęboko przekonany, że jeśli [Andrzej Duda] zostanie wybrany na prezydenta, mówię to o narodzie, to będziemy się z niego cieszyli (czasownik illokucyjny expositives; J. Hołub, dz. cyt.). 
Kategorię commissives reprezentują ogółem cztery teksty prasowe, spośród których jedynie jeden ma związek z budowaniem wizerunku KEP:

To jest sprzeczne z naszą tradycją, kulturą i ja nie tylko jako polityk, ale też jako prawnik, mąż i ojciec, mówię „nie”, nie zgadzam się, żeby ktokolwiek zwalczał moją rolę. Tak. Ona jest ukształtowana na tradycji, na podstawie religii i tej wiary, którą ja wyznaję, i ja chcę w tym pozostać - podkreśla Duda (czasownik illokucyjny commissives; źródło: tamże).

Pozostałe zaś trzy wypowiedzi wspomnianej relacji nie ujawniają:

Będę czynił wszelkie starania, aby na koniec mojej prezydentury Polacy uważali, że byłem tych orderów godny - mówił Duda, odbierając insygnia Orderu Białego i Krzyża Wielkiego Orderu Odrodzenia Polski (czasownik illokucyjny commissives; P. Majewski, Duda chce być niezłomny, „Rzeczpospolita” 2015, 7.08, s. A4).

W imieniu rządu i swoim własnym chciałbym zadeklarować otwartość i gotowość do pełnej współpracy z panem prezydentem w sprawach bezpieczeństwa i obrony narodowej - mówił wicepremier Tomasz Siemoniak podczas przekazania zwierzchności nad armią (czasownik illokucyjny commissives; tamże).

W wieczór wyborczy obiecał Pan: „Chciałbym, żeby po pięciu latach prezydentury jak najwięcej moich rodaków mogło mówić z przekonaniem: Andrzej Duda jest prezydentem wszystkich Polaków (czasownik illokucyjny commisives; A. Kondzińska, Nawet prezydent podlega konstytucji, „Gazeta Wyborcza” 2015, 5.08, s. 6).

Z kolei do behabitives zostały zaklasyfikowane cztery teksty prasowe, spośród których dwa mają związek z wizerunkiem KEP:

Niech każdy duchowny (niezależnie od stopnia święceń), który: sprzeniewierzył się cnocie czystości, żyje od lat w grzechu ciężkim ze swoją "gospodynią", „kuzynem”, „organistą", jest ojcem, alkoholikiem, zatracił się w umiłowaniu bogactwa, stanie podczas sumy w kościele albo w swojej katedrze i powie wiernym: Przepraszam za zgorszenie z powodu (tu należy wskazać), które stało się moim udziałem (czasownik illokucyjny behabitives; [Frater in Christo], Czy jesteście gotowi na prawdę, „Gazeta Wyborcza" 2015, 14-16.08, s. 22-23).

Niezależnie od intencji, które przyświecały księżom odprawiającym mszę w kościele Sióstr Wizytek, przeprosiny Bronisława Komorowskiego odebrane zostały na 
zasadzie: „biskupi mają kamienne serca, my, kapłani, kierujemy się miłością i miłosierdziem i dlatego przepraszamy" (czasownik illokucyjny behabitives; T. Krzyżak, Księża kontra biskupi...).

Dwa natomiast tego związku nie ujawniają:

Życzę mu dobrej prezydentury przez najbliższe pięć lat oraz tego, żeby nikt nie obrzucał go błotem, nie wymyślał na ulicy i nie buczał (czasownik illokucyjny behabitives; M. Olejnik, Habemus Dudam, „Gazeta Wyborcza” 2015, 7.08, s. 6).

Przez wiele lat dziennikarze prawicowi w niewybredny sposób walczyli z Bronisławem

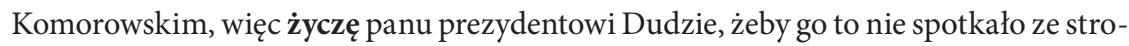
ny tych, którzy na niego głosowali (czasownik illokucyjny behabitives; tamże).

\section{Wizerunek Konferencji Episkopatu Polski jako podmiotu wspierającego politycznie Andrzeja Dudę i partię Prawo i Sprawiedliwość po zakończonych wyborach prezydenckich w 2015 r.}

Autor zbadał również teksty pod kątem ich odniesienia do Konferencji Episkopatu Polski, wyróżniając następujące kategorie:

- KEP jako niezaangażowany aktor polityczny (KEP zostaje ukazana jako podmiot dystansujący się od udzielania poparcia politycznego Dudzie albo aktor polityczny zachowujący zasady katolickiej nauki społecznej w odniesieniu do swojej obecności w sferze publicznej);

- KEP jako zaangażowany aktor polityczny (KEP zostaje ukazana jako podmiot wspierający politycznie Dudę albo aktor polityczny niezachowujący zasad katolickiej nauki społecznej w odniesieniu do swojej obecności w sferze publicznej).

Autor odniósł wyżej wymienione kategorie do tekstów, w których zostały użyte czasowniki illokucyjne oraz ogółem do wszystkich tekstów. W ten sposób mógł zweryfikować, czy obecność czasowników illokucyjnych wpływa w zauważalny sposób na wizerunek prasowy KEP w poddanych analizie tytułach prasowych.

We wszystkich analizowanych tekstach prasowych, które ukazywały biskupów polskich jako stronę zaangażowaną w dyskurs polityczny i popierających Andrzeja Dudę, również czasowniki illokucyjne tam występujące służyły ukazaniu Konferencji Episkopatu Polski jako zaangażowanego aktora politycznego.

Tabela 4 prezentuje liczbę tekstów, w których KEP ukazana zostaje jako niezaangażowany oraz zaangażowany aktor polityczny we wszystkich tekstach ogółem oraz w tekstach, w których występuje przynajmniej jeden czasownik illokucyjny i w tekstach, gdzie brak określeń wskazujących na moc illokucyjną. 
Tabela 4. Wizerunek Konferencji Episkopatu Polski w „Gazecie Wyborczej” i „Rzeczpospolitej” jako zaangażowanego i niezaangażowanego aktora politycznego

\begin{tabular}{|c|c|c|}
\hline & $\begin{array}{l}\text { KEP jako zaan- } \\
\text { gażowany aktor } \\
\text { polityczny }\end{array}$ & $\begin{array}{l}\text { KEP jako niezaan- } \\
\text { gażowany aktor } \\
\text { polityczny }\end{array}$ \\
\hline $\begin{array}{l}\text { Ogółem wszystkie teksty „GW” } \\
\text { i „Rzeczpospolitej” }\end{array}$ & 23 & 12 \\
\hline Wszystkie teksty „Rzeczpospolitej” & 2 & 8 \\
\hline $\begin{array}{l}\text { Teksty w „Rzeczpospolitej”, w których nie } \\
\text { występują określenia wskazujące na moc } \\
\text { illokucyjną }\end{array}$ & 0 & 5 \\
\hline $\begin{array}{l}\text { Teksty w „Rzeczpospolitej”, w których występują } \\
\text { określenia wskazujące na moc illokucyjną }\end{array}$ & 2 & 3 \\
\hline Wszystkie teksty „GW” & 21 & 4 \\
\hline $\begin{array}{l}\text { Teksty w "GW", w których nie występują } \\
\text { określenia wskazujące na moc illokucyjną }\end{array}$ & 10 & 1 \\
\hline $\begin{array}{l}\text { Teksty w „GW”, w których występują określenia } \\
\text { wskazujące na moc illokucyjną }\end{array}$ & 11 & 3 \\
\hline
\end{tabular}

Źródło: opracowanie własne.

Autor przywołuje przykłady tekstów prasowych, w których występują określenia wskazujące na moc illokucyjną, i które przedstawiają KEP jako zaangażowanego aktora politycznego na rzecz Dudy i PiS:

„Konferencja Episkopatu Polski serdecznie gratuluje Prezydentowi-Elektowi!” - taki entuzjastyczny wpis zamieścił rano na Twitterze rzecznik Episkopatu ks. Józef Kloch. Episkopat nie czekał z gratulacjami na oficjalne wyniki wyborów, tak jak to miał w zwyczaju do tej pory. A z gratulacji sprzed pięciu laty dla Komorowskiego raczej wiało chłodem (K. Wiśniewska, Czy Kościół pomógł Dudzie?). 
Kościół hierarchiczny bardziej wierzy w siłę wpływów politycznych, w siłę ustanawiania prawa zgodnego z nauką Kościoła niż w siłę ewangelicznego przekazu. [...] Mam wrażenie, że biskupi myślą już tylko o prawnej i politycznej ofensywie, w której głównym wykonawcą będzie Andrzej Duda i wojsko PiS (D. Wielowieyska, Andrzej Duda i biskupi).

Istnieją także teksty prasowe, w których brak określeń wskazujących na moc illokucyjną, ale w podobny jak wyżej sposób ukazują KEP, np.:

Gratulacje ze strony hierarchów są zrozumiałe, jeśli weźmie się pod uwagę rolę, jaką w kampanii wyborczej odegrały katolickie media i kapłani angażujący na rzecz kandydata PiS-u swój duchowy autorytet (D. Kozłowska, Katolicyzacja polityki, „Gazeta Wyborcza" 2015, 10.06. s. 9).

Kościół robił Andrzejowi Dudzie kampanię w kościołach podczas mszy zwanej świętą, i gdyby nie to, obecny prezydent elekt nie uzyskałby decydującej przewagi (J. Mikołajewski, Kongres racjonalnej Polski, „Gazeta Wyborcza” 2015, 12.06, s. 10).

Pośród analizowanych tekstów były również takie, które ukazywały KEP jako niezaangażowaną politycznie. W tekstach tych obecność czasowników illokucyjnych lub ich brak nie zostały wykorzystane do ukazania polskich biskupów jako tych, którzy wspierają Dudę.

Ogółem osiem tekstów „Rzeczpospolitej”, niezależnie od obecności lub braku w nich określeń wskazujących na moc illokucyjną, prezentuje Episkopat Polski jako podmiot niezaangażowany w politykę, niewspierający Dudy i ugrupowań prawicowych - to 80\% wszystkich tekstów „Rzeczpospolitej”. Z kolei cztery teksty "Gazety Wyborczej” prezentują podobnie polskich biskupów, co stanowi tylko 16\% wszystkich tekstów tego dziennika. Owa dysproporcja pomiędzy dwoma tytułami wskazuje dostrzegalny brak obiektywizmu „GW” i pewien z góry przyjęty cel zaprezentowania KEP jako struktury politycznie zaangażowanej, popierającej Dudę. Biorąc pod uwagę tylko teksty, w których użyto czasowników illokucyjnych wyniki są następujące: dla „Rzeczpospolitej” - trzy teksty (6o\% tych tekstów „Rzeczpospolitej”, w których są czasowniki illokucyjne) oraz trzy teksty w „GW” (21\% tych tekstów „GW”, w których znalazły się czasowniki illokucyjne). Obecność lub brak określeń wskazujących na moc illokucyjną nie wpływa zatem znacząco na sposób budowania wizerunku KEP przez „Rzeczpospolitą” i „Gazetę Wyborczą”. 


\section{Weryfikacja hipotez badawczych i wnioski}

Przeprowadzona analiza pozwala na weryfikację hipotez badawczych.

Łączna liczba czasowników illokucyjnych w poddanych analizie tekstach wynosi 34, co daje średnią 0,97 czasownika w każdym tekście. Biorąc pod uwagę tylko te czasowniki illokucyjne, które odnoszą się do budowania wizerunku prasowego KEP po zakończonej drugiej turze wyborów prezydenckich w 2015 r., średnia ta wynosi 0,71 .

Najbardziej reprezentatywną grupą czasowników illokucyjnych w poddanej analizie próbie badawczej są verdictives. Poprzez ich użycie piszący eksponuje swój osąd rzeczywistości. Drugą z kolei najbardziej reprezentatywną grupę stanowi kategoria expositives, której zasadniczą funkcją jest przedstawianie argumentacji, poglądów oraz zastosowanych wyrażeń. Rozróżnienie tych dwóch kategorii stanowiło dla autora problem ze względu na zbieżność funkcji, jakie pełnią w dyskursie. Obie kategorie wyraźnie eksponują opinię piszącego tekst, stąd nie wywołuje zdziwienia fakt ich najczęstszego stosowania w dwóch analizowanych tytułach prasowych o charakterze zasadniczo opiniotwórczym. Brak kategorii exercitives wynika z tego, że rolą dziennikarza nie jest ustanawianie prawa czy obsadzanie osób na stanowiska w urzędach sfery publicznej, ale raczej informowanie i proponowanie interpretacji rzeczywistości politycznej.

Obecność tzw. czasowników illokucyjnych nie determinuje sposobu przedstawiania Konferencji Episkopatu Polski jako aktora politycznego po zakończonych wyborach prezydenckich w $2015 \mathrm{r}$.

Użycie czasowników illokucyjnych jest zasadniczo zbieżne z linią programową „Gazety Wyborczej” i „Rzeczpospolitej”. W przekonaniu autora niniejszej pracy wypowiedzi illokucyjne mogą być zastosowane w celu podkreślenia polityczności bądź apolityczności KEP. Istotny będzie zatem kontekst i sposób użycia tych słów, które pełnią jedynie funkcję pomocniczą w kształtowaniu wizerunku. To jedynie pewne narzędzie, jakkolwiek pomocne, w kształtowaniu obrazu rzeczywistości prasowej. Najważniejsza pozostaje jednak intencja piszącego, która zadecyduje, jak wykorzystać czasowniki illokucyjne. Możliwa jest również rezygnacja z ich zastosowania, która nie pozbawia piszącego tekst dziennikarski szansy zaproponowania pewnej wizji rzeczywistości czy wykreowania określonego wizerunku.

Czasowniki illokucyjne potwierdzają linię polityczną tytułu prasowego, która dotyczy sposobu prezentacji polskich biskupów jako zaangażowanych bądź niezaangażowanych politycznie. Akty illokucyjne jedynie wzmacniają, bardziej eksponują sposób oceny i sposób budowania wizerunku KEP.

Analiza pokazała, że istnieje zbieżność w prezentowaniu linii politycznej KEP między tekstami, w których są zawarte czasowniki illokucyjne a tekstami, gdzie nie odnotowuje się ich obecności. 


\section{Bibliografia}

\section{Monografie naukowe}

Austin J.L., How to Do Things with Words, Oxford 1975.

Austin J.L., Wypowiedzi performatywne, [w:] J.L. Austin, Mówienie i poznawanie. Rozprawy i wykłady filozoficzne, przeł. B. Chwedeńczuk, Warszawa 1993, s. 311-334.

Dmochowski A., Kościót „Wyborczej”. Największa operacja resortowych dzieci, Lublin 2014. Martinich A.P., Communication and Reference, Berlin 1984.

Osika G., Procesy i akty komunikacyjne, Kraków 2011.

Reichert J., Sprechakttheorie nach John Langshaw Austin, München 2009.

Sławek J., Obraz Kościoła katolickiego na łamach polskiej prasy codziennej z perspektywy realizowanych stereotypów, [w:] Język religijny dawniej i dziś, t. 1, red. S. Mikołajczak, ks. T. Węcławski, Poznań 2004, s. 396-406.

Zdunkiewicz D., Akty mowy, [w:] Wspótczesny język polski, red. J. Bartmiński, Wroclaw 1993, s. 259-270.

\section{Źródła internetowe}

Homilia Prymasa Polski abp. Wojciecha Polaka wygłoszona podczas Mszy Świętej w dniu zaprzysiężenia Prezydenta RP Andrzeja Dudy, 6.08.2015, http://episkopat.pl/homilia-prymasa-polski-abp-wojciecha-polaka-wygloszona-podczas-mszy-swietej-w-dniu-zaprzysiezenia-prezydenta-rp-andrzeja-dudy/ [dostęp: 12.08.2016].

Kucharczak F., Jak Kościół łamał cieszę wyborcza, http://gosc.pl/doc/2505426.Jak-Kosciol-lamal-cisze-wyborcza [dostęp: 12.08.2016].

Lisicki P., Paweł Lisicki o miejscu „Rzeczpospolitej” na mapie polskiej prasy, pęknięciach na prawicy oraz o głębokim sensie wydarzeń po $10 \mathrm{kwietnia,} \mathrm{rozm.} \mathrm{przepro-}$ wadziła K. Wigura, „Kultura Liberalna” 2011, nr 3, 18.01, http://kulturaliberalna. pl/2011/01/18/pawel-lisicki-o-,,rzeczpospolitej”-polskiej-prawicy-i-scenie-publicznej-po-10-kwietnia/ [dostęp: 12.08.2016].

List gratulacyjny Prezydium KEP do Prezydenta Andrzeja Dudy, 25.05.2015, http:// episkopat.pl/list-gratulacyjny-prezydium-kep-do-prezydenta-andrzeja-dudy/ [dostęp: 12.08.2016].

Najbardziej opiniotwórcze polskie media w 2015 roku. Analiza częstotliwości cytowania poszczególnych mediów przez inne media na podstawie przekazów prasowych, telewizyjnych $i$ radiowych $z$ okresu od 1 stycznia do 31 grudnia 2015 roku, http://www.imm.com.pl/sites/default/files/raporty/najbardziej_opiniotworcze_ media_w_2015.pdf [dostęp: 12.08.2016].

Ustawa Prawo prasowe $z$ dnia 26 stycznia 1984 r., art. 10.2, http://www.krrit.gov.pl/ Data/Files/_public/Portals/0/regulacje-prawne/polska/prawo-prasowe.pdf [dostęp: 12.08.2016]. 
Wittenberg A., „Gazeta Wyborcza” i „Rzeczpospolita” manipulują czy działaja zgodnie $z$ liniq? Statystyki $w$ slużbie ideologii, http://natemat.pl/21123,gazeta-wyborcza-i-rzeczpospolita-manipuluja-czy-dzialaja-zgodnie-z-linia-statystyki-w-sluzbie-ideologii [dostęp: 12.08.2016].

Wstęp abp. Stanisława Gądeckiego do Mszy świętej inaugurującej urzędowanie nowego Prezydenta Rzeczpospolitej Polskiej, 6.08.2015, http://episkopat.pl/wstep-do-mszy-swietej-inaugurujacej-urzedowanie-nowego-prezydenta-rzeczpospolitej-polskiej/ [dostęp: 12.08.2016].

\section{Dzienniki}

Cytaty z radiomaryjnego zjazdu. Biskup, Kaczyński, Jasna Góra, „Gazeta Wyborcza” 2015, 16.07, s. 6.

[Frater in Christo], Czy jesteście gotowi na prawdę, „Gazeta Wyborcza” 2015, 14-16.08, s. $22-23$.

Grochal R., In vitro i Duch Święty, „Gazeta Wyborcza” 2015, 25-26.07, s. 2.

Gulbinowicz H., Ojczyzna jest wolna, rozm. przeprowadził J. Nizinkiewicz, „Rzeczpospolita" 2015, 12.08, s. A6.

Hołub J., Radio Maryja: Dzięki Bogu wygrat Duda, „Gazeta Wyborcza” 2015, 16.06, s. 6. Kondzińska A., Duda: To bzdura, że się nie da, „Gazeta Wyborcza” 2015, 7.08, s. 2.

Kondzińska A., Nawet prezydent podlega konstytucji, „Gazeta Wyborcza” 2015, 5.08, s. 6.

Kondzińska A., Szpala I., Cały dzień z Andrzejem Dudą, „Gazeta Wyborcza” 2015, 6.08 , s. 3.

Kozłowska D., Katolicyzacja polityki, „Gazeta Wyborcza” 2015, 10.06, s. 9.

Krzyżak T., Czy Andrzej Duda ma zadatki na zbawiciela?, „Rzeczpospolita” 2015, 9.06, s. A8.

Krzyżak T., Kłopot z ceremoniałem, „Rzeczpospolita” 2015, 29.07, s. A5.

Krzyżak T., Księża kontra biskupi. Nowa linia podziału, „Rzeczpospolita” 2015, 11.08., s. A6.

Krzyżak T., Państwo wyznaniowe straszy, „Rzeczpospolita” 2015, 26.05, s. A2.

Krzyżak T., Politycy nie moga żyć bez Kościoła, „Rzeczpospolita” 2015, 22.07, s. A9.

Kumor W., Sto dni gegania, „Gazeta Wyborcza” 2015, 18-19.07, s. 2.

Majewski P., Duda chce być niezłomny, „Rzeczpospolita” 2015, 7.08, s. A4.

Makowski J., Między kropidłem a smartfonem, „Rzeczpospolita” 2015, 11.08, s. A11.

Mikołajewski J., Kongres racjonalnej Polski, „Gazeta Wyborcza” 2015, 12.06, s. 10.

Obirek S., Nie jest przesadą mówienie o iranizacji Polski, rozm. przeprowadziła D. Wodecka, „Gazeta Wyborcza” 2015, 18-19.07, s. 30-31.

Olejnik M., Habemus Dudam, „Gazeta Wyborcza” 2015, 7.08, s. 6.

Olejnik M., Jasny grom..., „Gazeta Wyborcza” 2015, 24.07, s. 4.

Olejnik M., Świecki pasterz, „Gazeta Wyborcza” 2015, 17.07, s. 2.

Orliński W., Hejterami się nie wygrywa, „Gazeta Wyborcza” 2015, 12.06, s. 8. 
Siedlecka E., Dobro wspólne czy kościelne, „Gazeta Wyborcza” 2015, 8-9.08, s. 6. Steinhagen D., Kościót z PiS na wybory, „Gazeta Wyborcza” 2015, 13.07, s. 4. Środa M., Przyszłość należy do ateistów?, „Gazeta Wyborcza” 2015, 17.06, s. 2. Środa M., W czwartek, „Gazeta Wyborcza” 2015, 5.08, s. 2.

Terlikowski T., Jak zostać nieostentacyjnym katolikiem, „Rzeczpospolita” 2015, 10.08, s. A2.

Wielowieyska D., Abp Dziegga i jego rewolucja moralna, „Gazeta Wyborcza” 2015, 7.08, s. 8. Wielowieyska D., Andrzej Duda i biskupi, „Gazeta Wyborcza” 2015, 9.06, s. 5.

Wilgocki M., Zwolennicy i przeciwnicy obu prezydentów w jednym kościele, „Gazeta Wyborcza" 2015, 6.08, s. 3.

Wiśniewska K., Co ma Boże Ciało do in vitro?, „Gazeta Wyborcza” 2015, 5.06, s. 4. Wiśniewska K., Czy Kościót pomógł Dudzie?, „Gazeta Wyborcza” 2015, 26.05, s. 8. Wiśniewska K., Diecezjalne tuby PiS, „Gazeta Wyborcza” 2015, 24.06, s. 3. Zdort D., Ciemny lud tego nie kupit, „Rzeczpospolita” 2015, 27.05, s. A6.

\section{Rola aktów illokucyjnych w kształtowaniu wizerunku prasowego Konferencji Episkopatu Polski. Studium ogólnopolskich dzienników "Gazeta Wyborcza” i „Rzeczpospolita”}

Streszczenie

Celem artykułu jest określenie roli zastosowania czasowników illokucyjnych verdictives, exercitives, commissives, behabitives i expositives $\mathrm{w}$ budowaniu wizerunku prasowego. Autor w podjętych badaniach odwołuje się do pragmatycznej analizy działań językowych Johna Langshawa Austina oraz zagadnień prasoznawczych dotyczących definiowania i kreowania wizerunku. W tekście dokonana zostaje analiza tekstów ogólnopolskich dzienników „Rzeczpospolita” i „Gazeta Wyborcza”, z okresu 25 maja-15 sierpnia 2015 r. pod kątem określenia wizerunku Konferencji Episkopatu Polski w wymiarze jej zaangażowania politycznego, po zakończonych wyborach prezydenckich w $2015 \mathrm{r}$.

Słowa kluczowe: akty illokucyjne, wizerunek prasowy, wybory, polityka 


\section{The Function of Illocutionary Acts in Shaping of Press Image of Polish Episcopal Conference as a Political Actor after the Presidential Election of 2015 The Study of Polish Magazines "Gazeta Wyborcza" and "Rzeczpospolita"}

Summary

The purpose of this article is to determine the role of the use of verbs illocutionary verdictives, exercitives, commissives, behabitives and expositives in building the press image. Author in the studies undertaken refers to the theory of speech acts of John Langshaw Austin and to journalistic issues of defining and creating the image. In the text are analysed press articles of magazines "Rzeczpospolita" and "Gazeta Wyborcza", in the period between May 25, 2015 and August 15, 2015, for determining the image of the Polish Episcopal Conference in the dimension of his political engagement, after concluded the presidential election of 2015.

Keywords: illocutionary acts, press image, elections, policy

ks. Rafał Leśniczak - doktor nauk humanistycznych w zakresie nauk o poznaniu i komunikacji społecznej (Pontificia Università della Santa Croce, Rzym 2010; nostryfikacja doktoratu - Wydział Filozofii i Socjologii UMCS w Lublinie 2012). Adiunkt w Katedrze Teorii, Aksjologii i Prawa Mediów Instytutu Edukacji Medialnej i Dziennikarstwa UKSW w Warszawie. Wykładowca pedagogiki mediów masowych w WSD w Łodzi. Jest autorem ponad 30 publikacji naukowych z zakresu mediów, religii i polityki. Jego zainteresowania naukowe koncentrują się wokół komunikowania politycznego, analizy wizerunku prasowego instytucji, organizacji, liderów politycznych, procesów personalizacji i mediatyzacji, public relations oraz teorii komunikowania masowego.

E-mail: rafalles@vp.pl. 